\title{
LEXICAL ERRORS IN THE ACQUISITION OF THE LATVIAN LANGUAGE AS THE SECOND LANGUAGE AT PRESCHOOL AGE
}

\author{
Ingēra Tomme-Jukēvica \\ Child's Language Research Centre, \\ Riga Teacher Training and Educational Management Academy, Latvia
}

\begin{abstract}
The lexical component plays a significant role in the first stages of language acquisition. However, there has been relatively little research into the lexical errors of young second language learners at preschool age. Moreover, the Russophone children's Latvian language as a second language has not been analyzed in lexical aspect so far. The aim of this study is to investigate types of lexical errors and the reasons for their occurrence. The data on 12 six-seven year old children, who study L2 (Latvian) in a formal language learning context were collected. Children's speech (using the author's compiled vocabulary test for identification of productive skills of single-word vocabulary) was recorded on a dictaphone. Errors were identified, classified and tabulated. The findings illustrate three categories of lexical errors: interlingual (L1-transfer), intralingual (L2-influence) and mutual (both L1and L2-influence) in the oral presentations of the participants. Semantic, morphological, and phonological types of errors featuring in them were identified. The results imply that children (like adults) learning L2 vocabulary use the strategy of LI (Russian) lexical transfer (e.g., borrowing, coinage) to cope with the lexical difficulties imposed by the new vocabulary. Determination of the particular lexical errors, and establishment of the causes that generate them will help the teacher delimitate their approach to Latvian vocabulary teaching. To prevent children's errors some recommendations are proposed. It is advisable to devise and incorporate special exercises and activities directed to the practice of problematic lexical areas.
\end{abstract}

Keywords: child second language acquisition, Latvian language vocabulary, L1-transfer, L2influence, preschool age Russophone children, types of lexical errors.

\section{Introduction}

Vocabulary is the most essential part in the second language acquisition (SLA) process (Chomsky, 1968; Ellis, 1997; James, 1998; Llach, 2005). Several linguists have proposed the importance of putting lexis, not grammar, at the centre of the classroom in order to help learners develop their ability to use second language for real communication. According to Lewis (1993:89), language consists of grammaticalized lexis, not lexicalised grammar and grammar as structure is subordinate to lexis. Little (1994:106) also argues that words inevitably come before structures. It is crucial to learn and use words 
Ingêra Tomme-Jukèvica. Lexical Errors in the Acquisition of the Latvian Language as the Second Language at Preschool Age

appropriately as communication breakdowns generally originate in lexical limitations and lack of knowledge.

When young learners are the recipients of the instruction, the particular cognitive stage of children learning a second language influences their use and acquisition of vocabulary. Karmiloff and Karmiloff-Smith (2001:28) assert that „the types of errors and modifications that children make, when imitating speech provide us with vital insight into the child's level of linguistic knowledge. If the teacher knows the kind of errors his students make he is in a much better position to prevent his students from making those errors again". By identifying, describing and classifying lexical errors we may learn much about what type of lexical items the learner knows or does not know, what is the source of the problem, or how to tackle that problem (Corder 1981; Ellis 1997). Error analysis is basically the linguistics analysis and it reveals the different underlying processes that are involved in the phenomenon of language learning. However, up-to-date, only relatively few studies have been concerned with lexical errors of preschool L2 learners. Moreover, In Latvian linguistics bilingual preschool children's Latvian language as the second language has so far not been adequately addressed, the Russophone children's Latvian language has not been analyzed in lexical aspect. Thus, the reason for the focus on vocabulary errors is the scarcity of such studies. This study is set to investigate the vocabulary of the Russophone preschoolers' L2 (Latvian language). The aim of the study is to provide an insight into the single-word vocabulary errors committed by the Russophone preschool children learning Latvian as L2. The study aims to analyze and focus on the different types of errors highlighting the causes and reasons behind them. Based on the main purpose of the research and the scope of the study, the author will try to find answers to the following research questions: What are the types of lexical errors made by Russophone preschool children? What are the causes of these errors: is it L1 (Russian) which causes them or L2 (Latvian)? Thus, speech samples of the Russian preschoolers applying the single-word vocabulary test were collected. The errors were then detected, analysed and classified. The sources were classified into three categories: L1-influence, L2-influence, and mutual (both L1- and L2-influence). It is expected that information obtained from this study will help us gain some insight into the phenomenon.

\section{Previous studies}

Several scholars and SLA researchers (e.g. Corder, 1981; Selinker 1992; Richards, 1974; Dulay\&Burt, 1974; Dulay et al., 1982; Ellis, 1997; James, 1998; Tomasello, 2007) maintain that errors in themselves are of great importance to scholars insomuch as they are to teachers and learners. L2 learner errors have 
been investigated thoroughly as to what errors are, their types and classifications. They have been studied for their importance in understanding the nature of SLA process, the strategies used by the L2 learner, how and why only few learners achieve native-like competence. Several studies tackle different types of errors including syntactic, phonological, semantic, etc. Dulay et al. (1982) found that errors committed by SL learners can be ascribed to L1, i.e. interlingual, L2, i.e. intralingual, both LI and L2, i.e. ambiguous and those having no identifiable source, i.e. unique. Four types of errors: „developmental”, „,interlingual”, „ambiguous” and „others” errors have been discussed. Developmental/intralingual errors are "similar to those made by children learning a target language as their first language" (Dulay et al., 1982:165). Interlingual errors are similar in structure to a semantically equivalent phrase or sentence in the learners' native language; i.e. what Selinker (1972) calls interference (negative transfer). To identify interlingual errors, researchers usually translate the learner's production (e.g. phrases, sentences etc.) into the learner's native language to examine whether similarities exist. The third type is ambiguous errors, which are those that could be classified either as developmental or interlingual since they reflect the learner's native language structure and at the same time are of the type found in the speech of children acquiring their first language. The last type of errors is categorized as "other". Dulay and Burt (1973) classified such errors as "unique". Errors of this type are items that do not fit into any other category. Furthermore, they are unique to second language learners.

According to Llach and Gómez (2007), lexical errors represent a hint into vocabulary acquisition in a second language given the fact that they may demonstrate a lack of lexical knowledge, possible communication strategies used by the learners, the organization of the mental lexicon, and/or the development of lexical competence. Previous studies on lexical errors have used a variety of error classifications. Regarding lexical error taxonomies, Llach (2011: 91) concludes that there are many different taxonomies of lexical error in SLA literature that in most cases are developed to fit the data and not vice versa. Therefore, it is difficult for lexical error taxonomies to be adapted for other data sets. Different taxonomies are concerned with different issues: explanations of whether the lexical errors are semantic or formal in nature; description of the focus on the surface form of the error such as wrong lexical choice, omission, wrong order; explanation of the source of lexical error; lexical errors can be classified relating to their cause - mental processes underlying the lexical error, such as overgeneralization; semantic transfer and confusion of related words that include interlingual, intralingual and teaching-induced errors. Taxonomies can deal with the classification of lexical errors depending on the linguistic level on which the error occurs - phonology, morphology, syntax; they can examine 
Ingêra Tomme-Jukèvica. Lexical Errors in the Acquisition of the Latvian Language as the Second Language at Preschool Age

which word classes are the most affected by errors, as well as there are mixed types of taxonomies of lexical errors (Llach 2011: 76-87). However, only few of such studies deal with lexical errors of young children and fewer have probed their sources and consequences.

The particular cognitive stage of young learners influences the use and acquisition of L2 vocabulary. The role of the mother tongue is very important, when speaking in the second language, especially to beginner and young learners. Beginner learners lack the vocabulary to say all what they want to say, therefore, one of the most recurrent strategies is to make use of the mother tongue, either by borrowing words directly from the L1, or by adapting L1 words to L2 conventions (Celaya \& Torras 2001; Naves et al., 2005). Another typical error of beginner learners and learners in the early stages of learning is mispronunciation (Celaya \& Torras 2001). This type of error affects different word classes: nouns, verbs, adjectives, belonging to the various semantic fields. A substitution takes place when a word is used instead of another one. For instance, nouns and verbs are mistaken. The lack of lexical errors of a particular linguistic item can be the result of mastery but also of inhibition in use, a phenomenon generally known as avoidance (Schachter, 1974). Although it is difficult to identify the underlying cause of a wrong linguistic form, lexical errors can be very valuable in getting a deeper and more accurate understanding of the processes of lexical acquisition. Examination of the lexical errors produced by Russian young learners provides us with an insight into the vocabulary acquisition process and reveals what areas of the second language lexis do preschoolers have problems with when speaking in Latvian.

\section{Methodology}

\section{Participants}

The participants of the study were twelve Russophone children acquiring their L2 (Latvian language) in formal context according to the Minority Preschool Education Program (with instruction in Russian) and the Latvian Language Program of X preschool education establishment. All participants had started studying Latvian from the age of 3-4 years in 10-12 min classes. At the age of $6-7$ they had 30 min classes three times a week. In formal context children acquired their L2 deliberately and developed the language skills purposefully. However, the efforts to ensure the informal language environment were also observed since learners were motivated to learn the language through play and were provided guidance in Latvian in real everyday situations. The participants of the study were tested in a kindergarten room twice during the first and second term in the school year of 2014/ 2015. 


\section{Research Instrument and Procedure}

In order to examine preschoolers' knowledge of Latvian lexis and investigate types of lexical errors, the author's compiled vocabulary test for identification of productive skills of single-word vocabulary was administered. The test involved specific lexial units of fifteen concrete thematic groups, for example, parts of the body, e. g., galva, roka (head, hand), domestic animals, e. g., kaķis, suns (cat, dog), vegetables, e. g., burkāns, gurķis (carrot, cucumber), basic colours, e.g., sarkans, zils (red, blue), daily activities, e. g., $\bar{e} d$, gul (eat, sleep), etc., introduced in the preschool education documents (the Minority Preschool Education Program (2012); the Latvian Language Program of X preschool education establishment (2008)).The total number of lexical units tested constituted 114 words. Before proceeding on with the test, the participants were instructed in Russian to make sure that they understood the instructions of the test. The participant was asked to name an object or a living being that the researcher indicated and that was depicted on one of the four pictures presented at the same time. Each lexical unit that was produced by the participant was then marked, the scoring being either correct (1 point) or incorrect/ not named (0 point). Erroneous words were transcribed and analyzed.

\section{Error count}

As indicated by Corder (1981), error analysis can be carried out through three stages: recognition, description, and explanation. Lennon (1991 : 182) views „error” as ,a linguistic form or combination of forms which, in the same context and under similar conditions of production, would, in all likelihood, not be produced by the speaker's native speaker counterparts." For the purpose of the present study a lexical error is defined as a deviant committed at the level of lexical choice as a result of violating lexical rules particular to the Latvian language. Because morphological errors are confined to word structure and therefore cannot be ignored when lexical errors are discussed, in this study derivational errors were included. Inflectional affix errors that are mainly governed by grammatical processes were excluded from this analysis. To answer the questions of the study (What are the types of lexical errors made by Russophone preschool children? What are the causes of these errors?) the types of lexical errors were identified and classified according to the sources underlying their production: L1-based (interlingual) errors, L2-based (intralingual) errors and L1- and L2- based (mutual). The error framework was created which represents an eclectic kind of classification the categories of which appear in Dulay et al. (1982), James (1998), Llach (2005). It has also been created basing on the author's own observations and interpretations of the lexical errors committed by participants in the study. It is important to draw attention to the fact that sometimes there was some overlap between error 
Ingēra Tomme-Jukèvica. Lexical Errors in the Acquisition of the Latvian Language as the Second Language at Preschool Age

categories and it was not always possible to be certain of the reason(s) for a particular error, therefore precise categorisation was not always possible. However, a detailed typology of lexical errors has been created (see Table 1).

\section{Results and Discussion}

The analysis of the data yields three main sources of errors: interlingual, intralingual and mutual errors. The table below (Table 1) shows that change of code errors which represent interlingual and mutual errors took the form of borrowings and coinages. Borrowing from the native language while producing in the L2 is quite common in the Russophone preschoolers' Latvian as L2 acquisition (for example, pyku,туфли, юбка, рубаха, помидор, свекла, лук, тыква, слива, груша, виноград, сок, хлеб, торт, корова, коза, собака, голубь, варона, утка, берёза, ёлка, клён, весна, кровать, улииа, дорога, магазин, светофор, красный, автобусс). An explanation of this use could be the lack of such Latvian words in the learners' repertoire and hence, the learner uses L1 words instead, it may happen either consciously or unconsciously. Apart from borrowing the word directly from their mother tongue, learners also adapt some Russian words so that they sound like Latvian ones (for example, šarfis, pidžaks, rubaškas, hlebs, torts, slives, vinogrāds, limons, ogurcis, vorobejs, varons, korovs, kljons, dubs, stuls, zerkole, domis, magazins), what James calls coinage - „inventing a word from L1” (James, 1998:149). Although there are many different types of lexical inventions (Dewaele, 1998), the most frequent among those that arise from L1 (Russian) are coinages or adaptations of L1 words to the grammatical conventions of L2 (using Latvian endings of nouns). The reason behind coining new words is that the participants lack the knowledge of the tested lexical unit so they resort to word coinage.

There were some cases of semantic errors known as calques or literal translations (for example, melnamaize for /rupjmaize/ (brown bread), baltsmaize for /baltmaize/ (wheat bread)). The errors thought to be induced by L2 took the form of underextension (e. g., oga (berry) for /vīnogas/ (grapes)), overextension (e. g., düraini (mittens) for /cimdi/ (gloves), sandelis (sandals) for /kurpes/ (shoes)) and words with phonic resemblance., i.e., similar in form but different in meaning - synforms or similar form (e. g., zakis (hare) for /zekes/ (socks), lapa (leaf) for /lapsa/ (fox), pele (mouse) for /pīle/, siena (wall) for /seja (face), gailis (rooster) for /galds/ (table). The errors of this type, as the name implies, result from confusion between the incorrect and correct words to be used. Confused, the learner chooses the incorrect word and substitutes it for the correct one. These errors exhibit a tendency of a wrong choice of a word similar to that intended and thus resulting in a semantically deviant utterance. According to such studies, these errors are developmental and are caused by 
intralingual association and the lack of the sufficient knowledge that enables the learners to differentiate between forms and their uses. Thus, the source of such errors is L2, i.e. Latvian. Some errors were dissimilar in form and different in meaning - dissimilar form (e. g., lācis (bear) for /ziema/ (winter), ezeris (lake) for /parks/ (park)). In a few cases, there was no relationship between the word used and the required one (e. g., klucis (block) for /ausis/ (ears), žogs (fence) for /mētelis/ (coat)). Thus, Russophone children encounter difficulties in learning Latvian semantics and so they commit errors which can be attributed to the L2 or intralingual errors. The above analysis of vocabulary errors show that to deliver the meanings of words, children use the strategy of association in learning and using L2 words. They rely on interlingual as well as intralingual association and use substitution an coining new words and avoidance strategies that cause errors in language performance. They either use simpler lexis instead of the difficult ones or avoid the words completely producing the lexis as the findings of the study show.

A relatively large number of the intralingual errors were due to the use of an incorrect morphological ending of the word either in gender (e.g., degune, vedere, zabakas, makaronas, vinogi, balode) or declension (e.g., bieta, tomātis, bumbiers, galve). One erroneously produced lexical unit (vinoga for /vīnogas/ (grapes)) which was categorized into L1-based errors was used with incorrect singular number in ending - in the Latvian language a bunch of grapes is always pronounced with plural ending (vinogas) while in Russian there is no plural ending for this word (виноград).

When a word is wrongly pronounced, such a word will be semantically distorted. It has been found that distortion due to phonological errors committed by the subjects of this study fall into misselection and omission types of errors. Misselection of one or more phonemes is committed in such a way that the learner selects an incorrect vowel-based ype or consonant-based type of phoneme(s) for a correct one (e. g., vevere for /vāvere/ (squirrel), azis for /ezis/ (hedgehog), trolejbas for/trolejbuss/ (trolleybus), tranvajs for /tramvajs / (tram). The source of such errors is either L1 (e. g. skafs for/skapis (wardrobe), fiolets for /violets/ (violet) or L2 (e. g. saldujums for/saldejums/ (ice-cream), opelsins for /apelsīns/ (orange), devāns for /dīvāns/ (sofa). The reason behind such errors could be the inability to pronounce the word properly. Omitting one or more phonemes from a word also results in semantically deviant utterances (e. g. bukans for /burkāns/ (carrot), trovajs for /tramvajs/ (tram), kartupe for /kartupelis/ (potatoe)). The errors of omission are L2 based. That is, the source of such errors is not L1 rather L2 itself. 
Ingēra Tomme-Jukēvica. Lexical Errors in the Acquisition of the Latvian Language as the Second Language at Preschool Age

Table 1 Classification of Lexical Errors

\begin{tabular}{|c|c|c|c|c|}
\hline Errors & Error Type & Definition & Examples & $\begin{array}{l}\text { Error } \\
\text { Source }\end{array}$ \\
\hline \multirow{3}{*}{ 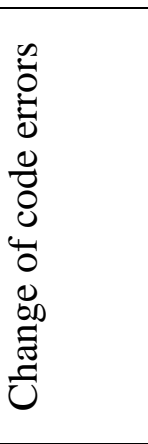 } & Borrowing & $\begin{array}{l}\text { L1 (Russian) word is used in } \\
\text { L2 (Latvian) without any } \\
\text { change }\end{array}$ & $\begin{array}{l}\text { помидор /tomāts/ } \\
\text { (tomato), } \\
\text { собака /suns/ (dog) }\end{array}$ & \multirow{2}{*}{ 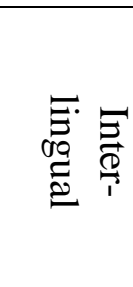 } \\
\hline & $\begin{array}{l}\text { Wrong } \\
\text { borrowing }\end{array}$ & $\begin{array}{l}\text { Wrong L1 word is used in L2 } \\
\text { without any change }\end{array}$ & $\begin{array}{l}\text { щуба (fur coat) } \\
\text { /mētelis/ (coat) }\end{array}$ & \\
\hline & Coinage & $\begin{array}{l}\text { A word that does not exist in } \\
\text { L2 (Latvian) based on L1 } \\
\text { (Russian) is created }\end{array}$ & $\begin{array}{l}\text { glaz+is /acis/ (eyes), } \\
\text { limon }+s \text { /citrons/ } \\
\text { (lemon) }\end{array}$ & \multirow{2}{*}{ 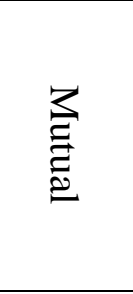 } \\
\hline \multirow{5}{*}{ 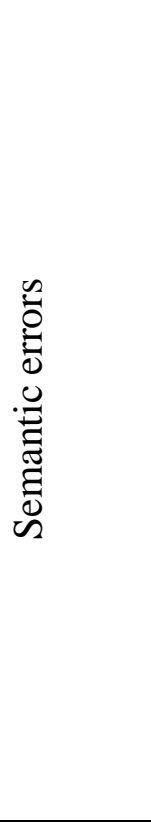 } & Translation & $\begin{array}{l}\text { L1 (Russian) word is translated } \\
\text { literally into L2 (Latvian) }\end{array}$ & $\begin{array}{l}\text { melnamaize } \\
\text { /rupjmaize/ (brown } \\
\text { bread) }\end{array}$ & \\
\hline & $\begin{array}{l}\text { Underexten } \\
\text { sion }\end{array}$ & $\begin{array}{l}\text { A more general L2 term is used } \\
\text { where a specific one is needed; } \\
\text { the meaning is narrowed down }\end{array}$ & $\begin{array}{l}\text { oga (berry) /vīnogas/ } \\
\text { (grapes) }\end{array}$ & \multirow{6}{*}{ } \\
\hline & $\begin{array}{l}\text { Overextensi } \\
\text { on }\end{array}$ & $\begin{array}{l}\text { An overly specific L2 term is } \\
\text { used; the meaning is } \\
\text { overspecified }\end{array}$ & $\begin{array}{l}\text { dūraiņi (mittens) } \\
\text { /cimdi/ (gloves) }\end{array}$ & \\
\hline & $\begin{array}{l}\text { Similar } \\
\text { form }\end{array}$ & $\begin{array}{l}\text { An L2 (Latvian) word similar } \\
\text { in form (sound similarity) but } \\
\text { different in meaning is used }\end{array}$ & $\begin{array}{l}\text { siena (wall) /seja/ } \\
\text { (face), zaķis (hare) } \\
\text { /zek̦es/ (socks) }\end{array}$ & \\
\hline & $\begin{array}{l}\text { Dissimilar } \\
\text { form } \\
\text { (Wrong } \\
\text { word) }\end{array}$ & $\begin{array}{l}\text { An L2 word neither similar in } \\
\text { form nor meaning is used }\end{array}$ & $\begin{array}{l}\text { burkāns (carrot) } \\
\text { /gurķis/ (cucumber) }\end{array}$ & \\
\hline \multirow{3}{*}{ 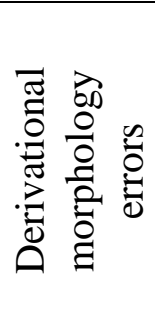 } & Gender & $\begin{array}{l}\text { A word with the incorrect } \\
\text { gender ending is used }\end{array}$ & $\begin{array}{l}\text { zābakas /zābaki/ } \\
\text { (boots) }\end{array}$ & \\
\hline & Declension & $\begin{array}{l}\text { A word applying the incorrect } \\
\text { declination ending is used }\end{array}$ & $\begin{array}{l}\text { galve /galva/ (head), } \\
\text { bieta /biete/ (beetroot) }\end{array}$ & \\
\hline & Number & $\begin{array}{l}\text { A word with the incorrect } \\
\text { number in ending is used }\end{array}$ & $\begin{array}{l}\text { vīnoga/vīnogas/ } \\
\text { (grapes) }\end{array}$ & \multirow{2}{*}{ 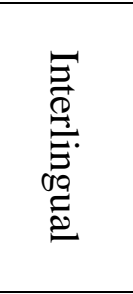 } \\
\hline \multirow{3}{*}{ 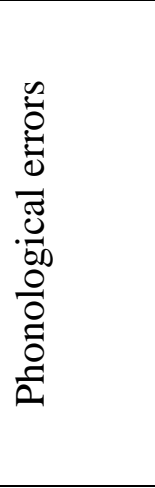 } & $\begin{array}{l}\text { Misselec- } \\
\text { tion }\end{array}$ & $\begin{array}{l}\text { A word with the incorrect L2 } \\
\text { phoneme(s) (vowel-based type } \\
\text { and consonant-based type) is }\end{array}$ & $\begin{array}{l}\text { skafs /skapis/ } \\
\text { (wardrobe), fiolets } \\
\text { /violets/ (violet) }\end{array}$ & \\
\hline & & 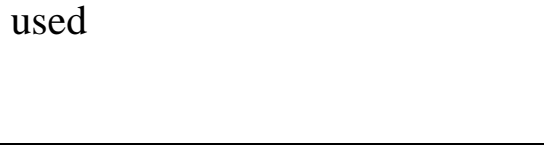 & $\begin{array}{l}\text { vevere /vāvere/ } \\
\text { (squirrel), tranvajs } \\
\text { /tramvajs/ (tram) }\end{array}$ & \multirow{2}{*}{ 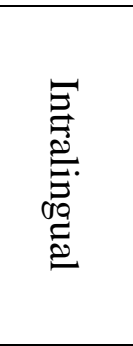 } \\
\hline & Omission & $\begin{array}{l}\text { A word which lacks an L2 } \\
\text { phoneme(s) (vowel-based type } \\
\text { and consonant-based type) is } \\
\text { used }\end{array}$ & $\begin{array}{l}\text { bukans /burkāns/ } \\
\text { (carrot), spoga } \\
\text { /spogulis/ (mirror) }\end{array}$ & \\
\hline
\end{tabular}




\section{Conclusion}

The typology of lexical errors that describes lexical errors and interprets them according to psycholinguistic criteria (sources of the participants' errors: LI, L2, mutual), and linguistic criteria (at what linguistic level it occurs: semantic, morphological, phonological) has been proposed. The main types of lexical errors have been described. Concerning the sources of the participants' errors, lexical transfer (borrowing) is the most visible effect of the L1 presence. The other noticeable effect of L1 can be seen in mutual word-formation errors, when children combine Russian lexical items with a linguistic feature from Latvian (coinage) or literally translate the part of the word from their L1 (translation). Intralingual transfer, errors attributed to the difficulty of the L2, includes semantic substitution errors (underextension, overextension) and wordchoice errors attributable to the failure to select appropriate words due to intralingual phonetic association (similar form) and lack of appropriate linguistic knowledge (dissimilar form). The common L2 source is the insufficient knowledge children have about Latvian morphology which makes them commit derivational morphology errors (gender, declension, number). As for the sources of the phonological errors committed by Russophone preschoolers, there are two different sources of such errors, namely, L1 (misselection) and L2 (misselection, omission). However, it should be noted that apart from the L1 and L2, the performance of the children may be affected by other variables such as the individual characteristics of the learner and learning environment, e. g., the amount of input in quantitative and qualitative terms can make a difference in errors L2 learners produce.

Based on these findings, the teacher of Latvian should pay attention to how to make their learners aware of the differences between L1 and L2 to minimize their roles in committing such errors. This could be taken into account by teachers in choosing which semantic area they should pay attention to more than any other in designing their classes and teaching resources. When presenting semantic units in classroom, practicing low frequent words can have important consequences in the learners' use of vocabulary. Such words can cause problems for preschoolers and need to be treated more explicitly in comparison with words which are more frequent and easily learned and used. Teachers should focus on the form approach aimed at raising consciousness, and propose activities to make learners improve their production. Rehearsing and repeating the problematic lexical units through paying attention to linguistic form can help improve learners' accuracy while explicit instruction and intentional learning can be combined with a contrastive approach, where the L1 and L2 are compared and similarities and differences singled out. 
Ingēra Tomme-Jukēvica. Lexical Errors in the Acquisition of the Latvian Language as the Second Language at Preschool Age

To conclude, one can say that identifying and treating lexical errors can help the teacher to prevent the learners from making them in future. Both in developing teaching resources and organizing lessons it is advisable to put more emphasis on and give more consideration to problematic lexical areas. Currently, this aspect is not given sufficient attention in Latvia. For filling this gap it is proposed to develop special exercises, as well as provide methodological recommendations for the teachers of the Latvian language.

\section{References}

Celaya, M. L. \& Torras, M. R. (2001). L1 influence and EFL vocabulary: do children rely more on L1 than adult learners? Retrieved from http://www.ub.edu/GRAL/pubs/ AEDEAN01CelayaTorras.pdf

Chomsky, N. (1968). Language and Mind. New York: Harcourt Brace Jovanovich.

Corder, S. (1973). Introducing Applied Linguistics. Harmondsworth: Penguin Books Ltd.

Corder, S. (1981). Error Analysis and Interlanguage. Oxford: Oxford University Press.

Dewaele, J.M. (1998). Lexical inventions: French interlanguage as L2 versus L3. Applied Linguistics, 19 (4), 471-490.

Dulay, H. \& Burt, M. (1973). Should we Teach Children Syntax? Language Learning. In R.L. Light \& M. Gutierrez (Eds.) Handbook for ESL Teachers (pp. 245-258). New York: New York State Department of Education.

Dulay, H. \& Burt, M. (1974). Errors and Strategies in Child Second Language Acquisition. TESOL Quarterly, 8(2), 129-136.

Dulay, H., Burt, M., Krashen, S. (1982). Language Two. New York: Oxford University Press.

Ellis, R. (1997). Second Language Acquisition. Oxford: Oxford University press.

James, C. (1998). Errors in Language Learning and Use: Exploring Error Analysis. Hong Kong: Addison Wesley Longman Limited.

Jiang, N. (2000). Lexical representation and development in a second language. Applied Linguistics, 21, 47-77.

Karmiloff, K. \& Karmiloff-Smith, A. (2001). Pathways to Language: from Fetus to Adolescent. Cambridge, Massachussets: Harvard University Press.

Lennon, P. (1991). Error: Some Problems of Definition, Identification, and Distinction. Applied Linguistics, 12(2), 180-195.

Lewis, M. (1993). The lexical approach: the state of ELT and a way forward. Hove: Language teaching publications.

Little, D. (1994). Words and their properties: arguments for a lexical approach to pedagogical grammar . In: T. Odlin (Eds.) Perspectives on Pedagogical Grammar (pp. 99-122). Cambridge: Cambridge University Press.

Llach, M. P. (2005). The Relationship of Lexical Error and their Types to the Quality of ESL Compositions: an Empirical Study. Porta Linguarum, 3, 45-57.

Llach, M. P. (2011). Lexical Errors and Accuracy in Foreign Language Writing. Bristol: Multilingual Matters.

Llach, M. P. \& Barreras Gómez, B. M. (2007). Childrens' Characteristics in Vocabulary Acquisition and Use in the Written Production. RESLA, 20, 9-26.

Naves, T., Miralpeix, I., Celaya, M.L. (2005). Who Transfer More ... and What? Crosslinguistic Influence in Relation to School Grade and Language Dominance in EFL. International Journal of Multilingualism, 2 (2), 113-134. 
Programma (2012). Mazākumtautību pirmsskolas izglītības mācību satura programma (ar krievu mācību valodu) [Minority Preschool Education Program (with instruction in Russian]. Retrieved from http://visc.gov.lv/vispizglitiba/saturs/dokumenti/programmas/ pirmsskolai/programma_mzkt_pirmsk_krievu.pdf.

Programma (2008). R̄̄gas X pirmsskolas izglìtības iestāde. Latviešu valodas programma [Latvian Language Program of Riga X preschool education institution].

Richards, J. (1974). Error Analysis: Perspectives on Second Language Acquisition. London: Longman.

Schachter, J. (1974). An error in error analysis. Language Learning, 24, 205-214.

Selinker, L. (1972). Interlanguage. International Review of Applied Linguistics, 10, 209-241.

Selinker, L. (1992). Rediscovering Interlanguage. London: Longman.

Tomasello, M. (2007). Cognitive Linguistics and First Language Acquisition. In: Geeraerts, D.\&Cuyckens, H. (Eds.) Handbook of Cognitive Linguistics (pp.1092-1112). Oxford: Oxford University Press. 